\title{
HIV Infection and Depression Among Opiate Users in a US Epicenter of the Opioid Epidemic
}

\author{
Cecile M. Denis ${ }^{1,6}$ (Diffany Dominique ${ }^{1} \cdot$ Peter Smith $^{1} \cdot$ Danielle Fiore $^{1} \cdot$ Yi-Chien Ku ${ }^{1} \cdot$ Angus Culhane ${ }^{1}$. \\ Debora Dunbar $^{1}$. Dana Brown ${ }^{1} \cdot$ Menvekeh Daramay ${ }^{1}$. Chelsea Voytek ${ }^{1} \cdot$ Knashawn H. Morales $^{2}$ - Michael B. Blank ${ }^{1}$. \\ Paul F. Crits-Christoph ${ }^{1} \cdot$ Steven D. Douglas ${ }^{4} \cdot$ Serguei Spitsin ${ }^{4} \cdot \operatorname{lan}$ Frank $^{3} \cdot$ Krystal Colon-Rivera $^{5}$. \\ Luis J. Montaner ${ }^{5}$ David S. Metzger ${ }^{1} \cdot$ Dwight L. Evans $^{1}$
}

Accepted: 23 December 2020 / Published online: 15 January 2021

(c) The Author(s), under exclusive licence to Springer Science+Business Media, LLC part of Springer Nature 2021

\begin{abstract}
Using a mobile research facility, we enrolled 141 opioid users from a neighborhood of Philadelphia, an urban epicenter of the opioid epidemic. Nearly all (95.6\%) met DSM-5 criteria for severe opioid use disorder. The prevalence of HIV infection $(8.5 \%)$ was more than seven times that found in the general population of the city. Eight of the HIV-positive participants $(67.0 \%)$ reported receiving antiretroviral treatment but almost all of them had unsuppressed virus (87.5\%). The majority of participants (57.4\%) reported symptoms consistent with major depressive disorder. Severe economic distress (60.3\%) and homelessness were common (57\%). Polysubstance use was nearly universal, $72.1 \%$ had experienced multiple overdoses and prior medication for opioid use disorder (MOUD) treatment episodes (79.9\%), but few currently engaged in addiction care. The prevalence, multiplicity and severity of chronic health and socioeconomic problems highlight consequences of the current opioid epidemic and underscore the urgent need to develop integrated models of treatment.
\end{abstract}

Keywords Opioid · HIV · Risk behavior · Depression · MOUD

\section{Resumen}

Utilizando un Centro de Investigación Móvil, inscribimos a 141 usuarios de opioides del vecindario de Filadelfia, un epicentro urbano de la epidemia de opioides. Casi todos $(95,6 \%)$ cumplieron con los criterios del DSM-5 para el trastorno del uso severo del consumo de opioides. La prevalencia de la infección de VIH (8,5\%) fue más de 7 veces superior a las encontrada en la población general de la ciudad. Ocho de los participantes con VIH positivo $(67,0 \%)$ reportaron haber recibido tratamiento antirretroviral pero casi todos tuvieron virus no suprimido (87,5\%). La mayoría de los participantes $(57,4 \%)$ informaron síntomas compatibles con el Desorden Depresivo Mayor. La angustia severa por lo económico (60,3\%) y las

Cecile M. Denis

cdenis@pennmedicine.upenn.edu

1 Department of Psychiatry, Perelman School of Medicine, University of Pennsylvania, Philadelphia, PA, USA

2 Department of Biostatistics, Epidemiology and Informatics, Perelman School of Medicine, University of Pennsylvania, Philadelphia, PA, USA

3 Department of Medicine, Perelman School of Medicine, University of Pennsylvania, Philadelphia, PA, USA

4 The Children's Hospital of Philadelphia, Philadelphia, PA, USA

5 The Wistar Institute, Philadelphia, PA, USA

6 Department of Psychiatry, Perelman School of Medicine, University of Pennsylvania, 3535 Market St, Suite 4000, Philadelphia, PA 19104-3309, USA 
personas sin hogar fueron comunes (57\%). El uso de múltiples sustancias fue casi universal, el $721 \%$ había experimentado múltiples sobredosis y previos medicamentos para el tratamiento del trastorno por consumo de opioides (MOUD) (79,9\%), pero muy pocos estaban comprometidos con la atención a las adicciones. La prevalencia, la multiplicidad y la seriedad de los problemas de salud crónica y los problemas socioeconómicos destacan las consecuencias de la actual epidemia de opioides y subrayan la urgente necesidad de desarrollar nuevos modelos de tratamiento integrados.

Palabras clave Palabras clave $\cdot$ Opioide $\cdot \mathrm{VIH} \cdot$ Comportamiento de riesgo $\cdot$ Depresión $\cdot$ MOUD

\section{Introduction}

While the COVID-19 pandemic has necessarily overshadowed all public health concerns globally, the opioid epidemic in the United States continues to be a significant public health crisis (1). It is estimated that 2 million people meet criteria for opioid use disorder in the United States (2). In 2018, 47,600 people died from opioid overdose (3). From 2001 to 2018, the number of opioid-related deaths increased by $345 \%$ (1), and currently, more than 130 people die every day from opioid overdose (3). The increased use of prescription opioids, heroin and, more recently, fentanyl (and its analogs) have accounted for the rapidly escalating mortality over the past 15 years (4-8).

Beyond the mortality attributable to overdose, this epidemic has brought with it an increased incidence and prevalence of HIV and HCV infections. HIV outbreaks have occurred in places that had never previously had an HIV problem as well as places where HIV infections among people who inject drugs (PWID) had been considered to be well controlled (9-12). Nationally, increases in new infections with HCV have coincided with increases in injection drug use (12-17). The opioid epidemic has also exacerbated other medical $(11,18-22)$ and mental health conditions (20, 23-28) and has propelled an expansion of housing instability and homelessness $(29,30)$.

The City of Philadelphia is an urban epicenter of the opioid epidemic in the United States $(31,32)$. Eight percent (about 120,000 inhabitants) of the city's population were estimated to have an opioid use disorder. At 49.2 opioid related deaths per 100,000, Philadelphia has the highest ageadjusted rate of fatal overdoses of any of the largest cities in the country. In 2019, 1,150 people died of opioid overdose in Philadelphia (33). Reversing a 25-year downward trend in the City, between 2016 and 2019 there has been a $151 \%$ increase in new HIV infections among PWID (34-36). Consequently, Philadelphia represents an important laboratory for testing meaningful interventions to treat opioid use disorder in high-risk populations, however, current data are limited regarding the characteristics of those most affected by the opioid epidemic in Philadelphia.
The current paper reports on data generated by a crosssectional study supported by the University of Pennsylvania Mental Health AIDS Research Center. The study was designed to inform on the capacity to recruit participants for future HIV prevention research in high-risk PWID using a mobile research facility and to assess the prevalence of HIV infection, viral suppression, risk behaviors and depression among individuals with opioid use disorder. Previous studies showed that depression is associated with risk behavior and poor adherence to antiretroviral treatment in previous studies (37-40). This paper reports on the characteristics (sociodemographic, infectious diseases, substance use, mental health, risk-behaviors) of opioid users who inject drugs in a neighborhood highly impacted by the opioid epidemic. We hypothesize that substance use and risky behavior are associated with both HIV status and mental health after adjusting for sociodemographic characteristics.

\section{Methods}

\section{Sample}

The study used a convenience sampling strategy to engage individuals who use opioid and have ever injected opioids in the past 30 days. To maximize representation of the target population, inclusion criteria were limited to age over 18 and meeting DSM-5 criteria for opioid use disorder. We targeted the Philadelphia neighborhood most severely impacted by the opioid epidemic (i.e., Kensington). This neighborhood is home to Prevention Point Philadelphia, one of the largest syringe exchange programs in the country and has an estimated population of 12,000 PWID, $80 \%$ of whom inject opioids. The neighborhood has a high prevalence of homelessness. Potential participants were recruited via street outreach and word of mouth. Given the rapid response to our presence, no print or social media advertisements were used. Our mobile research unit parked in a highly visible and easily accessible location in close proximity to places of drug sale and use. Individuals interested in participating were encouraged to stop by the mobile unit where they could be pre-screened for an enrollment interview by answering a set of questions designed to include confirmation of opioid use. 
Those who reported opioid use were then invited to complete an enrollment interview. Participants received US\$20 for their participation in the study visit that was typically completed within 45 min. The University of Pennsylvania Institutional Review Board approved the study prior to the initiation of any research activities in the community.

\section{Measures}

After completion of informed consent, a trained research staff provided HIV pre-test counseling and performed a rapid HIV test (Chembio Sure Check ${ }^{\circledR}$ HIV 1/2 Assay). While waiting for the rapid HIV test result, participants completed an interview conducted by the research staff. This interview gathered sociodemographic information, past and current substance use (drug use section of the Addiction Severity Index (41)), a checklist of the DSM-5 opioid use disorder criteria (42), addiction treatment and overdose history, medical and mental health diagnostic and treatment histories. The interview also included the Risk Assessment Battery (RAB) to evaluate injection- and sex-related risk behaviors $(43,44)$, and the Quick Inventory of Depressive Symptomatology (QIDS) to assess the severity of depressive symptoms $(45,46)$. If the rapid HIV test was positive or indeterminate, blood was drawn for confirmatory testing and viral load measurement. All participants also provided a urine specimen for rapid assessment of recent substance use. Following the assessment, all participants were encouraged to utilize harm reduction services, referrals were made to local addiction and mental health treatment providers, and all of those who tested positive for HIV and were out of care were linked and confirmed to be connected to HIV care.

\section{Statistical Analyses}

Given the design and exploratory aims of the study, the results presented here are primarily descriptive. For the analyses, a QIDS score higher than 13 is considered to indicate severe depressive symptoms and a high probability of a diagnosis of major depressive disorder (45-48). HIV viral load $<50$ copies $/ \mathrm{mL}$ were considered undetectable viral load (i.e., virally suppressed). All variables are reported with percentage or mean and standard deviation.

Significance testing on an exploratory basis was conducted to examine the relation of HIV-status to demographic, substance use, and risk behavior variables using non-parametric tests Kruskall-Wallis or Fisher's exact test comparing HIV-positive and HIV-negative participants.

Because depression has been shown to be associated with risk behavior and poor adherence to antiretroviral treatment in previous studies (37-40), we have examined the variables (demographic, substance use, medical conditions and risk behavior) associated with depression. All variables that have been found associated in univariate analysis, have been entered in a regression model. The Benjamini-Hochberg technique adjusting the p-values to control the false discovery rate (FDR) for multiple tests has been applied. In the model, likelihood-ratio test has been run to control of type I errors with multiple comparisons. All the analyses were performed using JMP Pro 14® (SAS Institute Inc., Cary, NC, USA).

\section{Results}

\section{Sample Demographic Characteristics}

The sample consisted of 141 opioid users who have ever injected opioids in the past 30 days, mainly men (70.9\%), White (63.8\%), about 40 years of age on average (Table 1 ). Their socioeconomic status was low, three-quarter of them were unemployed $(71.6 \%)$, reporting very low income (78.0\%), receiving public assistance $(75.9 \%)$, and more than half of them were homeless $(57.4 \%)$.

\section{Substance-Related Variables}

Almost all the participants $(\mathrm{n}=135,95.7 \%)$ met DSM 5 criteria for severe $(6+$ criteria) opioid use disorder, only $4(2.8 \%)$ met criteria for mild (2-3 criteria), and 2 (1.4\%) for moderate (3-4 criteria). They were using opioids for 12 years $($ mean $=12.1, \mathrm{SD}=9.9)$. The participants reported using mainly heroin $(99.3 \%)$ and fentanyl (69.5\%). They also reported using other opioids (19.1\%) and MOUD (buprenorphine and methadone). They were polysubstance users, and reported using tobacco (94.3\%), cocaine $(68.8 \%)$, cannabis $(41.8 \%)$, benzodiazepines (31.9\%) mostly non-prescribed (88.9\%), alcohol (28.4\%), and amphetamines/ methamphetamines (19.1\%), in the past 30 days (Table 1). These self-reports were supported by urine drug screen results. Agreement rates between self-reports and urine drugs screen were high: 0.83 for opioids, 0.88 for methadone, 0.82 for buprenorphine, 0.78 for cannabis, 0.75 for cocaine, 0.85 for amphetamines/ methamphetamines, 0.71 for benzodiazepines.

The majority $(\mathrm{n}=111,79.9 \%)$ reported a history of treatment for opioid use disorder, detoxification $(\mathrm{n}=107$, $76.4 \%)$ or MOUD $(n=111,79.9 \%)$. However, slightly more than a third $(37.6 \%)$ reported current treatment with methadone (14.2\%) or buprenorphine/naloxone (20.6\%). Among those who reported receiving MOUD, the adherence to treatment was rather low, with participants reporting taking their MOUD only 4 days in the past 30 days on average. 
Table 1 Characteristics of the sample $(n=141)$

\begin{tabular}{|c|c|c|c|}
\hline Variables & \multicolumn{3}{|c|}{ Descriptive value (n, \%, mean, SD) } \\
\hline \multicolumn{4}{|l|}{ Socio-demographic } \\
\hline Gender-males n $(\%)$ & \multicolumn{3}{|l|}{$100(70.9)$} \\
\hline \multicolumn{4}{|l|}{ Race-n (\%) } \\
\hline White & \multicolumn{3}{|l|}{$90(63.8)$} \\
\hline African-American / Black & \multicolumn{3}{|l|}{$32(22.7)$} \\
\hline Other & \multicolumn{3}{|l|}{$19(13.5)$} \\
\hline Ethnicity-latin(x) n (\%) & \multicolumn{3}{|l|}{$26(18.4)$} \\
\hline Age-mean $(\mathrm{SD})$ & \multicolumn{3}{|c|}{$40.5(10.4)-($ range $20-69)$} \\
\hline \multicolumn{4}{|l|}{ Marital status-n (\%) } \\
\hline Never married & \multicolumn{3}{|l|}{$82(58.2)$} \\
\hline Married/living w/partner & \multicolumn{3}{|l|}{$30(21.0)$} \\
\hline Divorced/separated & \multicolumn{3}{|l|}{$28(19.8)$} \\
\hline Widowed & \multicolumn{3}{|l|}{$6(4.3)$} \\
\hline \multicolumn{4}{|l|}{ Level of education- $\mathrm{n}(\%)$} \\
\hline Some high school & \multicolumn{3}{|l|}{$42(29.8)$} \\
\hline High school diploma & \multicolumn{3}{|l|}{$72(51.1)$} \\
\hline Some college & \multicolumn{3}{|l|}{$23(16.3)$} \\
\hline Work status-unemployed n (\%) & \multicolumn{3}{|l|}{$101(71.6)$} \\
\hline \multicolumn{4}{|l|}{ Income per year-n $(\%)$} \\
\hline Under poverty level $(<\$ 12,490)$ & \multicolumn{3}{|l|}{$85(60.3)$} \\
\hline$\$ 12,491-\$ 25,000$ & \multicolumn{3}{|l|}{$25(17.7)$} \\
\hline$>\$ 25,000$ & \multicolumn{3}{|l|}{$28(19.9)$} \\
\hline Running out of money for necessities-yes n (\%) & $134(95.0)$ & & \\
\hline Homeless-yes n (\%) & $81(57.4)$ & & \\
\hline Health Insurance-medicaid n (\%) & $131(92.8)$ & & \\
\hline Receive public assistance-yes n (\%) & & & \\
\hline Food stamps & $107(75.9)$ & & \\
\hline Supplemental security income & $9(6.4)$ & & \\
\hline Substance use & & & \\
\hline Urine drug screen $(\mathrm{n}=127)-\mathrm{n}(\%)$ positive & & & \\
\hline Opiates & $105(82.7)$ & & \\
\hline Methadone & $24(19.0)$ & & \\
\hline Buprenorphine & $31(24.8)$ & & \\
\hline Cannabis & $36(28.3)$ & & \\
\hline Cocaine & $81(63.8)$ & & \\
\hline Benzodiazepines & $29(23.0)$ & & \\
\hline Amphetamine & $5(4.0)$ & & \\
\hline Methamphetamines & $15(11.9)$ & & \\
\hline Self-report $(n=141)$ —use past 30 days & & & \\
\hline & $\mathrm{n}(\%)$ & Days-mean $(\mathrm{SD})^{*}$ & Main route- $\mathrm{n}(\%)$ \\
\hline Heroin & $140(99.3)$ & $26.7(7.2)$ & IV: $136(97.1)$ \\
\hline $\begin{array}{l}\text { Any other opiates (morphine, codeine, fentanyl) } \\
\text { Fentanyl only }\end{array}$ & $\begin{array}{l}106(75.2) \\
98(69.5)\end{array}$ & $18.4(13.5)$ & $\begin{array}{l}\text { IV: } 78(69.0) \\
\text { Oral: } 25(22.1) \\
\text { Sniff: } 10(8.8)\end{array}$ \\
\hline Methadone & $20(14.2)$ & $4.8(10.3)$ & Oral: $82(95.3)$ \\
\hline Buprenorphine & $29(20.6)$ & $3.7(7.8)$ & $\begin{array}{l}\text { Oral: } 82(90.1) \\
\text { IV: } 4(4.4)\end{array}$ \\
\hline Cannabis & $59(41.8)$ & $6.0(9.6)$ & Smoke: $112(91.1)$ \\
\hline Cocaine & $97(68.8)$ & $18.8(10.9)$ & $\begin{array}{l}\text { Smoke: } 57 \text { (45.6) } \\
\text { IV: } 46(36.8) \\
\text { Sniff: } 22(17.6)\end{array}$ \\
\hline Benzodiazepines & 45 (31.9) & $5.1(8.7)$ & Oral: 74 (94.9) \\
\hline
\end{tabular}


Table 1 (continued)

\begin{tabular}{llll}
\hline Variables & \multicolumn{2}{l}{ Descriptive value (n, \%, mean, SD) } \\
\hline Amphet/methamphetamine & $27(19.1)$ & $3.0(6.7)$ & $\begin{array}{l}\text { IV: } 28(49.1) \\
\text { Oral: } 18(31.6)\end{array}$ \\
Hallucinogens & $5(3.5)$ & $1.8(6.5)$ & $\begin{array}{l}\text { Oral: } 33(76.7) \\
\text { Smoke: } 9(20.9)\end{array}$ \\
Alcohol & & & Oral: $109(100)$ \\
Tobacco & $40(28.4)$ & $3.1(7.4)$ & Smoke: $137(100)$ \\
\hline
\end{tabular}

For overdose: means and Standard Deviation (SD) have been calculated among those who have reported overdose. For substance use: mean and SD have been calculated among those who have reported using the substance. Main route $=$ route that the subject reported to use the most. Urine drug screen was available for $\mathrm{n}=127$

About three-quarters $(\mathrm{n}=101,72.1 \%)$ experienced overdoses in their life (mean $=5.7, \mathrm{SD}=6.9$, range $1-50)$, a third $(\mathrm{n}=42,33.3 \%)$ reported several $($ mean $=8.8, \mathrm{SD}=3.0$, range 1-14) overdoses over the past 6 months.

\section{Infectious Diseases}

Twelve participants tested positive for HIV (8.5\%). Eight participants reported being aware of their HIV-status and reported receiving antiretroviral therapy (ART).

Blood sample has been collected for viral load measure for eight participants, three participants refused the phlebotomy (one of them reported receiving ART), one participant had poor vein access and blood could not safely be drawn in the mobile unit. Viral load measure was available for eight participants and seven of them (87.5\%) exhibited unsuppressed viral load (VL) (VL $>50$ copies/mL, range: 133-907,000). Among the $8 \mathrm{HIV}$-positive participants reporting taking ART, viral load was available for seven of them, and 6 of 7 (85.7\%) had unsuppressed viral load.

Eighty-two participants (58.2\%) reported being seropositive for Hepatitis $\mathrm{C}$, and a minority of them (2.8\%) reported receiving HCV treatment. However, $12.1 \%$ of the participants reported being cured for Hepatitis $\mathrm{C}$ at the time of the interview.

\section{Other Medical Conditions}

Other medical comorbidities were also prevalent in the sample. About two-thirds (65.2\%) of the participants reported having a chronic disease (cardiovascular, respiratory, neurological, digestive, metabolic, cancer), and two-thirds (68.5\%) reported receiving some treatment for chronic medical conditions.

\section{Risk Behaviors}

Table 2 displays drug-related and sex-related risk behaviors. Almost three-quarters of the participants (72.6\%) reported at least one injection-related risk behavior including sharing needle (27.0\%), rinse water (30.5\%), cooker (40.4\%), cotton (22.1\%), or sharing drugs with others by using one syringe to squirt or load the drugs into the other syringe (40.4\%). Three HIV-positive individuals (25\%) reported that someone used their needles after them.

Participants also reported sex-related risk behaviors. Among those who were sexually active in the past 6 months $(n=115,82 \%), 60(52 \%)$ reported multiple sexual partners and $69 \%$ used condoms inconsistently.

There was no difference in reported risk behaviors between HIV-positive and HIV-negative individuals.

\section{Mental Health}

The QIDS indicated that more than half of the participants (57.4\%) exhibited depressive disorder (QIDS score $>13$ ) (Table 3). In response to individual items, 16.3\% reported thinking of suicide or death several times a week, and $11.3 \%$ reported thinking of suicide or death several times a day in some detail or have tried to commit suicide (Table 3). Other psychiatric disorders were also commonly reported (Table 3). More than half (56.1\%) of the participants had received treatment for a psychiatric disorder in their life, mostly for mood disorder (50.4\%) and anxiety disorder $(41.1 \%)$. However, only a minority $(17.0 \%)$ reported currently receiving psychiatric treatment.

\section{Factors Associated with HIV Status}

The HIV status was not found associated with any demographic, substance use, medical or mental health variables collected in our study, and therefore we did not pursue multivariable models for this outcome.

\section{Factors Associated with Depression}

In univariate analysis, participants who had depressive disorder were more often Latin(x) (Pearson $\mathrm{Chi}^{2}=6.38$, Fisher's exact test $\mathrm{p}=0.02$ ), reported having at least one chronic disease other than HIV and Hepatitis C (Pearson 
Table 2 Drug and sex-related risk-behavior $(\mathrm{n}=141)$

\begin{tabular}{|c|c|c|c|}
\hline \multicolumn{4}{|l|}{ Risk assessment behaviors } \\
\hline \multicolumn{4}{|l|}{ Injection past month } \\
\hline Every day-n (\%) & \multicolumn{3}{|l|}{$112(79.4)$} \\
\hline Several days every week-n $(\%)$ & \multicolumn{3}{|l|}{$20(14.2)$} \\
\hline Few times per month-n (\%) & \multicolumn{3}{|l|}{$9(6.4)$} \\
\hline \multicolumn{4}{|l|}{ Source of syringes past month } \\
\hline Needle exchange program-n $(\%)$ & \multicolumn{3}{|l|}{$128(90.8)$} \\
\hline On the street-n $(\%)$ & \multicolumn{3}{|l|}{$34(24.1)$} \\
\hline \multirow[t]{2}{*}{ Place where users go to inject } & \multicolumn{3}{|l|}{$4(2.8)$} \\
\hline & $\begin{array}{l}\text { Sample } \\
(\mathrm{n}=141)\end{array}$ & $\begin{array}{l}\text { HIV-negative } \\
(\mathrm{n}=129)\end{array}$ & $\begin{array}{l}\text { HIV-positive } \\
(\mathrm{n}=12)\end{array}$ \\
\hline \multicolumn{4}{|l|}{ Injection-related risk behavior-past 6 months } \\
\hline $\begin{array}{l}\S \text { At least one injection-related risk behav- } \\
\text { ior-n }(\%)\end{array}$ & $102(72.3)$ & $94(72.9)$ & $8(66.7)$ \\
\hline Sharing needles-yes n $(\%)$ & $38(27.0)$ & $33(25.6)$ & $5(41.7)$ \\
\hline Use after someone & $29(20.6)$ & $24(18.6)$ & $5(41.7)$ \\
\hline Someone uses after you & $32(22.7)$ & $29(22.5)$ & $3(25.0)$ \\
\hline Sharing rinse water & $43(30.5)$ & $38(29.5)$ & $5(41.7)$ \\
\hline Sharing cooker & $57(40.4)$ & $51(39.5)$ & $6(50.0)$ \\
\hline Sharing cotton & $31(22.0)$ & $26(20.2)$ & $5(41.7)$ \\
\hline Sharing drugs/squirt/backload & $57(40.4)$ & $50(38.8)$ & $7(58.3)$ \\
\hline *RAB Drug-related score (out of 22) & $\begin{array}{l}5.2(4.7) \\
\text { Range: } 0-21\end{array}$ & $\begin{array}{l}5.2(4.7) \\
\text { Range } 0-21\end{array}$ & $\begin{array}{l}6.6(5.5) \\
\text { Range } 1-17\end{array}$ \\
\hline \multicolumn{4}{|l|}{ Sex-related risk behavior-past 6 months } \\
\hline Sexually active-yes n (\%) & $115(81.6)$ & $106(82.2)$ & $9(75.0)$ \\
\hline Multiple sexual partners & $60(52.2)$ & $55(42.6)$ & $5(41.7)$ \\
\hline No systematic condom use $-\mathrm{n}(\%)$ & $79(68.7)$ & $72(55.8)$ & $7(58.3)$ \\
\hline *RAB Sex-related score (out of 22) & $\begin{array}{l}3.9(2.7) \\
\text { Range: } 0-13\end{array}$ & $\begin{array}{l}3.9(2.7), \\
\text { Range } 0-13\end{array}$ & $\begin{array}{l}4.0(3.1) \\
\text { Range } 0-11\end{array}$ \\
\hline
\end{tabular}

${ }^{\S}$ At least one injection-related risk behavior included either/or sharing needle, rinse water, cooker, cotton, or drugs by using one syringe. Sharing drugs/ squirt/ backload means divided or shared drugs with others by using one syringe to squirt or load the drugs into the other syringe (e.g., backloading)

* Score of the drug and sex-related risk behavior sections of the Risk Assessment Battery (RAB) questionnaire
$\mathrm{Chi}^{2}=8.35$, Fisher's exact test $\left.\mathrm{p}=0.004\right)$, and reported one or more overdoses in the past 6 months (Pearson $\mathrm{Chi}^{2}=6.55$, Fisher's exact test $\mathrm{p}=0.01)$. No associations were found with other socio-demographic, substance use, HIV and Hepatitis C, and risk behavior variables. The variables associated with depression have been entered in a regression model. After Benjamini-Hochberg technique has been applied $\left(\mathrm{chi}^{2}=20.0, \mathrm{df}=3, \mathrm{p}<0.0002\right.$, lack of fit $\mathrm{chi}^{2}=3.84$, $\mathrm{df}=3, \mathrm{p}=0.43$ ), participants with depressive disorder were more likely Latin(x) $(\mathrm{OR}=3.3,95 \%$ CI 1.2-9.9), report at least one chronic disease other than HIV and Hepatitis $\mathrm{C}$ $(\mathrm{OR}=2.9,95 \%$ CI 1.4-6.4), and report one or more overdoses in the past 6 months $(\mathrm{OR}=2.3,95 \%$ CI 1.1-5.4).

\section{Discussion}

The City of Philadelphia is an epicenter of the opioid epidemic. Consequently, Philadelphia is an important laboratory in which to examine the epidemic's impact on those most affected. Nearly all of the opioid users recruited for this research met DSM-5 criteria for severe opioid use disorder. Polysubstance use was universal. Among these participants with an average age of 40 and 12 years of opioid use, most had experienced multiple overdoses and had a history of prior treatments for addiction. Depressive disorder was common as were reports of suicidal thoughts. History of psychiatric diagnoses and prior treatments for mental health disorders was reported by $56 \%$. While most (93\%) had Medicaid coverage, the great majority were not currently engaged in 
Table 3 Mental health status and factors associated with depression $(n=141)$

\begin{tabular}{|c|c|}
\hline Mental health & $\mathrm{n}(\%)$ \\
\hline \multicolumn{2}{|l|}{ Received treatment for any psychiatric disorders } \\
\hline Lifetime & $78(56.1)$ \\
\hline Past 30 days & $24(17.0)$ \\
\hline \multicolumn{2}{|l|}{ Received treatment for mood disorder } \\
\hline Lifetime & $71(50.4)$ \\
\hline Past 30 days & $20(14.2)$ \\
\hline \multicolumn{2}{|l|}{ Received treatment for anxiety disorder } \\
\hline Lifetime & $58(41.1)$ \\
\hline Past 30 days & $20(14.2)$ \\
\hline \multicolumn{2}{|l|}{ Quick inventory of depressive symptomatology (QIDS) } \\
\hline Mean (SD) & $12.8(6.1)$ \\
\hline No depression (total score: $0-5)-\mathrm{n}(\%)$ & $20(14.2)$ \\
\hline Mild depression (total score: $6-10)-n(\%)$ & $28(19.9)$ \\
\hline Moderate depression (total score: $11-15)-\mathrm{n}(\%)$ & $40(28.4)$ \\
\hline Severe depression (total score: $16-20)-n(\%)$ & $37(26.2)$ \\
\hline Very severe depression (total score: $21+$ )—n (\%) & $16(11.3)$ \\
\hline Depressive disorder (QIDS > 13)—n (\%) & $81(57.4)$ \\
\hline Item 12: think of suicide or death several times a week-n (\%) & $23(16.3)$ \\
\hline $\begin{array}{l}\text { Item 12: think of suicide or death several times a day or have tried to commit } \\
\text { suicide }-\mathrm{n}(\%)\end{array}$ & $16(11.3)$ \\
\hline Factors associated with depression (QIDS $>13)^{*}$ & Odds ratio $(95 \% \mathrm{CI})$ \\
\hline \multicolumn{2}{|l|}{ Ethnicity } \\
\hline No Latin(x) & 1 (Reference) \\
\hline Latin(x) & $3.3(1.2-9.9)$ \\
\hline \multicolumn{2}{|l|}{ Chronic disease other than HIV and Hepatitis C } \\
\hline No chronic disease & 1 (Reference) \\
\hline At least one chronic disease & $2.9(1.4-6.4)$ \\
\hline \multicolumn{2}{|l|}{ Overdose the past 6 months } \\
\hline No overdose & 1 (Reference) \\
\hline One or more overdoses & $2.3(1.1-5.4)$ \\
\hline
\end{tabular}

*Stepwise regression adjusted on race, ethnicity, chronic disease, overdose past 6 months $\left(\mathrm{chi}^{2}=20.0\right.$, $\mathrm{df}=3, \mathrm{p}<0.0002$, lack of fit $\mathrm{chi}^{2}=3.84, \mathrm{df}=3, \mathrm{p}=0.43$ ). Benjamini-Hochberg to control FDR has been applied. Tests and confidence intervals on odds ratios are likelihood ratio based care for either substance use or psychiatric problems. The prevalence of HIV infection among these participants was more than 7 times the rate seen in the general population in the city. Importantly, most of the HIV-infected individuals exhibited unsuppressed virus and few were fully engaged in HIV care. Chronic medical conditions and untreated HCV were common. The majority reported severe economic distress and homelessness.

Because we have targeted the neighborhood of Philadelphia most severely affected by the opioid epidemic, our sample consisted of high-risk polysubstance users and cannot be considered representative of all opioid users in Philadelphia. However, the study used a mobile research facility to provide easy access to people who used opioids and was able to recruit all participants in 6 weeks, and has demonstrated the feasibility of this approach to engage both those at high risk of infection as well as those able to transmit HIV to others.
Upon DEA analyses of street drug purchases, fentanyl is likely to be the most widely used substance. In many respects, the opioid epidemic in Kensington has become a fentanyl epidemic. Recent studies show that opioid users who use fentanyl exhibit more severe opioid use disorder, and were more likely to be polysubstance users (6). Within the myriad of severe opioid use disorder, we found that injection related risk behaviors were widely practiced. This high frequency may reflect the more frequent use of fentanyl. Due to the short half-life of fentanyl, injections occur more frequently and require a larger supply of sterile syringes and injection equipment. These risk data are also consistent with findings from a recent study that showed that injection related risk behaviors were more common among heroin and cocaine (speedball) users, a group that was highly represented in our sample (49). Sexual risks were also present. Among those who were sexually active (80\%), 
condom use was inconsistent and multiple sexual partners common. Collectively, these risk behaviors help to explain the current high rate of increase in HIV infections among PWID in Philadelphia. The prevalence of HIV infection in our sample $(8.5 \%)$ is significantly higher than that of the general population in the City of Philadelphia (1.2\%), and the estimated prevalence in PWID (6901 per 100,000) (35). Furthermore, HIV-positive individuals in our sample were less likely to have been linked to HIV care than overall HIVpositive individuals in Philadelphia $(66.7 \%$ versus $86.1 \%$, respectively), and the vast majority have been virally unsuppressed, forming a reservoir for potential transmission (34, $35)$. In order to achieve the goals of the Ending the HIV Epidemic initiative by 2030 (50), there will be a need to improve engagement and retention in HIV care as well as adherence to antiretroviral therapy. Similarly, HCV was also prevalent in our sample and although based on self-report, the prevalence in our sample (58.2\%) is close to the $55.5 \%$ reported in the literature among PWID (17), and very few have reported being in treatment for their HCV infection. This high rate of HCV among PWID has contributed to an increased incidence of HCV in the U.S. (51), more deaths than HIV (52) and should also be addressed in responding to the opioid epidemic (53).

There is strong evidence that engagement in medication for opioid use disorder (MOUD) decreases the incidence of HIV and HCV infection and improves retention and adherence in HIV and care $(54,55)$. However, our sample showing a high rate of prior treatment with medications for opioid use disorder (MOUD) is a reminder of the challenge of treating opioid use disorder. Longitudinal studies of methadone and buprenorphine/naloxone suggest that 5 -year retention rates are about $50 \%$ (56). The data also point to the missed opportunity and the need to support the development of new strategies to help retain individuals in treatment and to facilitate re-engagement in and access for those who leave effective treatment approaches.

Given the severity of opioid use disorder, it is not surprising that symptoms of depression were frequently reported. While depression is well documented as a co-morbid condition among those with opioid use disorder, QIDS scores reported here suggest that $57 \%$ of these participants would meet criteria for major depressive disorder. Fifty-six percent reported past treatment for psychiatric disorder, and only a small proportion (17\%) reported currently receiving care. Given the chronic nature of psychiatric disorders, the low rate of current treatment is of great concern. Depression and other psychiatric disorders are significant not only as a condition requiring treatment to improve health and quality of life, but their presence significantly complicates the treatment of opioid use disorder. There is a clear need for integrated programs able to address both substance use and mental health $(25,27,57)$. Polysubstance use, psychiatric disorders, low income and homelessness are known to increase the risk of overdose in opioid users $(58,59)$.

Both polysubstance use (6) and psychiatric disorder, depression in particular, have been shown to be associated with suicidality $(26,60)$. While the distinction between intentional and unintentional overdose is not easily defined, it is clear that a meaningful proportion of fatal overdoses are in fact suicide $(23,24,61,62)$. Importantly, in this sample, depression was found associated with overdose in the past 6 months. Given the high prevalence of recent thoughts of suicide (27\%) and lifetime (72\%) and recent (33\%) non-fatal overdoses, the risk of intentional overdose in this population is great (63). While these data describe an urgent need for suicide prevention interventions, they also highlight the need for targeted research to better inform those interventions.

\section{Conclusion}

The prevalence and severity of opioid use disorder, depression and other psychiatric problems, infectious and chronic diseases, combined with serious socioeconomic challenges experienced by the participants of this study highlight the enormous challenges in developing and implementing effective responses to the opioid epidemic. The common element in this syndemic cluster of conditions is severe opioid use disorder and consequently is the most important target for intervention.

The multiplicity of problems in these participants dramatically increases the vulnerability of this population to other social and health problems including infection with the SARS-CoV-2 virus $(64,65)$. It is clear that for the segment of the population most affected by the opioid epidemic, effective responses will need new delivery structures and strategies that integrate evidence-based treatments for opioid use disorder, mental health, and primary care. The remote treatment approaches implemented in response to the COVID-19 pandemic by primary and mental health care providers may hold promise in demonstrating ways of reaching those unable to become engaged in traditional models of care. The fact that this study was able to rapidly engage participants using a mobile research facility supports the potential of delivering services to those most in need, in their home neighborhood. It is imperative that we develop effective models of care for this most vulnerable segment of our population, because, as clearly demonstrated by the HIV epidemic, when the health of even a small segment of the population is threatened, the public health is at risk.

Acknowledgments This work was supported by the Penn Mental Health AIDS Research Center (P30-MH-097488), the Penn Center for AIDS Research (P30-AI-045008), other NIH grants: 
1UM1A1126620, R01DA048728, R01DA049666, Kean Family Professorship, and the Philadelphia Foundation (Roberts I. Jacobs Fund). The authors would like to thank Mack Taylor, Ashley Jackson, Ann Davidson, and Fritz Graham for their help in conducting the interviews. They would like to thank Anne Colon and Diego Ramirez for the translation of the abstract in Spanish.

Author contributions Drs. CD, DM, DE, KC-R, LM, MB, PC-C, SS, and $\mathrm{SD}$ contributed to the study conception and design. Material preparation and data collection were performed by TD, PS, DF, Y-CK, AC, $\mathrm{DD}, \mathrm{DB}, \mathrm{MD}$, and CV. Data analyses were performed by Drs. D, K, $M$. The first draft of the manuscript was written by Drs. D, M and E and all authors commented on previous versions of the manuscript. All authors read and approved the final manuscript.

\section{References}

1. Gomes T, Tadrous M, Mamdani MM, Paterson JM, Juurlink DN. The burden of opioid-related mortality in the United States. JAMA Netw Open. 2018;1(2):e180217.

2. Substance Abuse and Mental Health Services Administration. 2018 National survey on drug use and health. Rockville: Substance Abuse and Mental Health Services Administration; 2020.

3. U.S. Department of Health and Human Services. Opioid Crisis Statistics 2019 [updated August 19, 2019. https://www.hhs.gov/ opioids/about-the-epidemic/opioid-crisis-statistics/index.html.

4. Gladden RM, O'Donnell J, Mattson CL, Seth P. Changes in opioid-involved overdose deaths by opioid type and presence of benzodiazepines, cocaine, and methamphetamine -25 states, July-December 2017 to January-June 2018. MMWR Morb Mortal Wkly Rep. 2019;68(34):737-44.

5. Han B, Volkow ND, Compton WM, McCance-Katz EF. Reported heroin use, use disorder, and injection among adults in the United States, 2002-2018. JAMA. 2020;323(6):568-71.

6. Schepis TS, McCabe VV, Boyd CJ, McCabe SE. The epidemiology of prescription fentanyl misuse in the United States. Addict Behav. 2019;96:89-93.

7. Wilson N, Kariisa M, Seth P, Smith Ht, Davis NL. Drug and opioid-involved overdose deaths-United States, 2017-2018. MMWR Morb Mortal Wkly Rep. 2020;69(11):290-7.

8. Larney S, Tran LT, Leung J, Santo T, Jr., Santomauro D, Hickman $\mathrm{M}$, et al. All-cause and cause-specific mortality among people using extramedical opioids: a systematic review and meta-analysis. JAMA Psychiatry. 2019. https://doi.org/10.1093/pm/pnaa214

9. Burnett JC, Broz D, Spiller MW, Wejnert C, Paz-Bailey G. HIV Infection and HIV-associated behaviors among persons who inject drugs-20 cities, United States, 2015. MMWR Morb Mortal Wkly Rep. 2018;67(1):23-8.

10. Des Jarlais DC, Kerr T, Carrieri P, Feelemyer J, Arasteh K. HIV infection among persons who inject drugs: ending old epidemics and addressing new outbreaks. AIDS. 2016;30(6):815-26.

11. Schwetz TA, Calder T, Rosenthal E, Kattakuzhy S, Fauci AS. Opioids and infectious diseases: a converging public health crisis. J Infect Dis. 2019;220(3):346-9.

12. Perlman DC, Jordan AE. The syndemic of opioid misuse, overdose, HCV, and HIV: structural-level causes and interventions. Curr HIV/AIDS Rep. 2018;15(2):96-112.

13. Fraser H, Vellozzi C, Hoerger TJ, Evans JL, Kral AH, Havens J, et al. Scaling up hepatitis $\mathrm{C}$ prevention and treatment interventions for achieving elimination in the United States: a rural and urban comparison. Am J Epidemiol. 2019;188(8):1539-51.
14. Fraser H, Zibbell J, Hoerger T, Hariri S, Vellozzi C, Martin NK, et al. Scaling-up HCV prevention and treatment interventions in rural United States-model projections for tackling an increasing epidemic. Addiction. 2018;113(1):173-82.

15. Larney S, Peacock A, Leung J, Colledge S, Hickman M, Vickerman $\mathrm{P}$, et al. Global, regional, and country-level coverage of interventions to prevent and manage HIV and hepatitis $\mathrm{C}$ among people who inject drugs: a systematic review. Lancet Glob Health. 2017;5(12):e1208-20.

16. Center for Disease Control and Prevention. Surveillance for viral hepatitis-United States, 2017. Atlanta: Center for Disease Control and Prevention;2019.

17. Abara WE, Trujillo L, Broz D, Finlayson T, Teshale E, Paz-Bailey $\mathrm{G}$, et al. Age-related differences in past or present hepatitis $\mathrm{C}$ virus infection among people who inject drugs: national human immunodeficiency virus behavioral surveillance, 8 US cities, 2015. J Infect Dis. 2019;220(3):377-85.

18. Barocas JA, Morgan JR, Wang J, McLoone D, Wurcel A, Stein MD. Outcomes associated with medications for opioid use disorder among persons hospitalized for infective endocarditis. Clin Infect Dis. 2020. https://doi.org/10.1093/cid/ciaa062

19. Glei DA, Preston SH. Estimating the impact of drug use on US mortality, 1999-2016. PLoS ONE. 2020;15(1):e0226732.

20. Sumetsky N, Burke JG, Mair C. Opioid-related diagnoses and HIV, HCV and mental disorders: using Pennsylvania hospitalisation data to assess community-level relationships over space and time. J Epidemiol Commun Health. 2019;73(10):935-40.

21. Wong CY, Zhu W, Aurigemma GP, Furukawa N, Teshale EH, Huang YA, et al. Infective endocarditis among persons aged 18-64 years with HIV, hepatitis C infection, or opioid use disorder - United States, 2007-2017. Clin Infect Dis. 2020. https://doi. org/10.1093/cid/ciaa372

22. Kadri AN, Wilner B, Hernandez AV, Nakhoul G, Chahine J, Griffin B, et al. Geographic trends, patient characteristics, and outcomes of infective endocarditis associated with drug abuse in the United States from 2002 to 2016. J Am Heart Assoc. 2019;8(19):e012969.

23. Bohnert ASB, Ilgen MA. Understanding links among opioid use, overdose, and suicide. N Engl J Med. 2019;380(1):71-9.

24. Oquendo MA, Volkow ND. Suicide: a silent contributor to opioidoverdose deaths. N Engl J Med. 2018;378(17):1567-9.

25. Bogdanowicz KM, Stewart R, Broadbent M, Hatch SL, Hotopf M, Strang J, et al. Double trouble: psychiatric comorbidity and opioid addiction-all-cause and cause-specific mortality. Drug Alcohol Depend. 2015;148:85-92.

26. Fendrich M, Becker J, Hernandez-Meier J. Psychiatric symptoms and recent overdose among people who use heroin or other opioids: results from a secondary analysis of an intervention study. Addict Behav Rep. 2019;10:100212.

27. Jones CM, McCance-Katz EF. Co-occurring substance use and mental disorders among adults with opioid use disorder. Drug Alcohol Depend. 2019;197:78-82.

28. Williams SC, Davey-Rothwell MA, Tobin KE, Latkin C. People who inject drugs and have mood disorders-a brief assessment of health risk behaviors. Subst Use Misuse. 2017;52(9):1181-90.

29. Doran KM, Rahai N, McCormack RP, Milian J, Shelley D, Rotrosen J, et al. Substance use and homelessness among emergency department patients. Drug Alcohol Depend. 2018;188:328-33.

30. Yamamoto A, Needleman J, Gelberg L, Kominski G, Shoptaw S, Tsugawa Y. Association between homelessness and opioid overdose and opioid-related hospital admissions/emergency department visits. Soc Sci Med. 2019;242:112585. 
31. Drug Enforcement Administration. Drug-related overdose deaths in Pennsylvania, 2018. DEA; 2019. Contract No.: DEA-PHL-BUL-132-19.

32. Philadelphia Department of Public Health. Opioid Misuse and Overdose Report Philadelphia; 2020 February 13th, 2020.

33. Philadelphia Department of Public Health. Unintentional Drug Overdose Fatalities in Philadelphia, 2019. Philadelphia: Philadelphia Department of Public Health; 2020.

34. Philadelphia Department of Public Health. HIV continues to spread among people who inject drugs. Philadelphia: Philadelphia Department of Public Health; 2019.

35. Philadelphia Department of Public Health. AIDS activities coordinating office surveillance report, 2018. Philadelphia, PA: City of Philadelphia; 2019. p. 2019.

36. AIDS Activities Coordinating Office. Update on HIV outbreak among PWID in Philadelphia. Philadelphia: Philadelphia Department of Public Health; 2020.

37. Dasgupta S, Tie Y, Lemons A, Wu K, Burnett J, Shouse RL. Injection practices and sexual behaviors among persons with diagnosed HIV infection who inject drugs-United States, 2015-2017. MMWR Morb Mortal Wkly Rep. 2019;68(30):653-7.

38. Fojo AT, Lesko CR, Calkins KL, Moore RD, McCaul ME, Hutton HE, et al. Do symptoms of depression interact with substance use to affect HIV continuum of care outcomes? AIDS Behav. 2019;23(3):580-91.

39. Pence BW, Mills JC, Bengtson AM, Gaynes BN, Breger TL, Cook RL, et al. Association of increased chronicity of depression with HIV appointment attendance, treatment failure, and mortality among HIV-infected adults in the United States. JAMA Psychiatry. 2018;75(4):379-85.

40. Pettes T, Kerr T, Voon P, Nguyen P, Wood E, Hayashi K. Depression and sexual risk behaviours among people who inject drugs: a gender-based analysis. Sex Health. 2015;12(3):224-30.

41. McLellan AT, Cacciola JC, Alterman AI, Rikoon SH, Carise D. The Addiction Severity Index at 25: origins, contributions and transitions. Am J Addict. 2006;15(2):113-24.

42. Hasin DS, O'Brien CP, Auriacombe M, Borges G, Bucholz $\mathrm{K}$, Budney A, et al. DSM-5 criteria for substance use disorders: recommendations and rationale. Am J Psychiatry. 2013;170(8):834-51.

43. Metzger DS, Woody GE, McLellan AT, O'Brien CP, Druley P, Navaline $\mathrm{H}$, et al. Human immunodeficiency virus seroconversion among intravenous drug users in- and out-of-treatment: an 18-month prospective follow-up. J Acquir Immune Defic Syndr (1988) 1993;6(9):1049-56.

44. Navaline HA, Snider EC, Petro CJ, Tobin D, Metzger D, Alterman AI, et al. Preparations for AIDS vaccine trials. An automated version of the Risk Assessment Battery (RAB): enhancing the assessment of risk behaviors. AIDS Res Hum Retroviruses. 1994;10(Suppl 2):S281-3.

45. Reilly TJ, MacGillivray SA, Reid IC, Cameron IM. Psychometric properties of the 16-item quick inventory of depressive symptomatology: a systematic review and meta-analysis. J Psychiatr Res. 2015;60:132-40.

46. Rush AJ, Trivedi MH, Ibrahim HM, Carmody TJ, Arnow B, Klein $\mathrm{DN}$, et al. The 16-item quick inventory of depressive symptomatology (QIDS), clinician rating (QIDS-C), and self-report (QIDSSR): a psychometric evaluation in patients with chronic major depression. Biol Psychiatry. 2003;54(5):573-83.

47. Gao K, Wang Z, Chen J, Kemp DE, Chan PK, Conroy CM, et al. Should an assessment of Axis I comorbidity be included in the initial diagnostic assessment of mood disorders? Role of QIDS16-SR total score in predicting number of Axis I comorbidity. J Affect Disord. 2013;148(2-3):256-64.

48. Lamoureux BE, Linardatos E, Fresco DM, Bartko D, Logue E, Milo L. Using the QIDS-SR16 to identify major depressive disorder in primary care medical patients. Behav Ther. 2010;41(3):423-31.

49. Bartholomew TS, Tookes HE, Bullock C, Onugha J, Forrest DW, Feaster DJ. Examining risk behavior and syringe coverage among people who inject drugs accessing a syringe services program: a latent class analysis. Int J Drug Policy. 2020;78:102716.

50. Katz I, Jha AK. HIV in the United States: getting to zero transmissions by 2030. JAMA. 2019;321(12):1153-4.

51. Chou R, Dana T, Fu R, Zakher B, Wagner J, Ramirez S, et al. Screening for hepatitis $\mathrm{C}$ virus infection in adolescents and adults: updated evidence report and systematic review for the US Preventive Services Task Force. JAMA 2020;323:976

52. Ly KN, Hughes EM, Jiles RB, Holmberg SD. Rising mortality associated with hepatitis C virus in the United States, 2003-2013. Clin Infect Dis. 2016;62(10):1287-8.

53. National Academies of Sciences, Engineering, and Medicine. Opportunities to improve opioid use disorder and infectious disease services: integrating responses to a dual epidemic. Washington, DC: The National Academies Press; 2020.

54. Fanucchi L, Springer SA, Korthuis PT. Medications for treatment of opioid use disorder among persons living with HIV. Curr HIV/ AIDS Rep. 2019;16(1):1-6.

55. Platt L, Minozzi S, Reed J, Vickerman P, Hagan H, French C, et al. Needle and syringe programmes and opioid substitution therapy for preventing $\mathrm{HCV}$ transmission among people who inject drugs: findings from a Cochrane Review and meta-analysis. Addiction. 2018;113(3):545-63.

56. Hser YI, Evans E, Huang D, Weiss R, Saxon A, Carroll KM, et al. Long-term outcomes after randomization to buprenorphine/naloxone versus methadone in a multi-site trial. Addiction. 2016;111(4):695-705.

57. Barocas JA, Wang J, Marshall BDL, LaRochelle MR, Bettano A, Bernson D, et al. Sociodemographic factors and social determinants associated with toxicology confirmed polysubstance opioidrelated deaths. Drug Alcohol Depend. 2019;200:59-63.

58. Berg JM, Malte CA, Reger MA, Hawkins EJ. Medical records flag for suicide risk: predictors and subsequent use of care among veterans with substance use disorders. Psychiatr Serv. 2018;69(9):993-1000.

59. Kuo YF, Raji MA, Goodwin JS. Association of disability with mortality from opioid overdose among us medicare adults. JAMA Netw Open. 2019;2(11):e1915638.

60. Bohnert KM, Ilgen MA, Louzon S, McCarthy JF, Katz IR. Substance use disorders and the risk of suicide mortality among men and women in the US Veterans Health Administration. Addiction. 2017;112(7):1193-201.

61. Conroy SC, Bjork JM. Death ambivalence and treatment seeking: suicidality in opiate addiction. Curr Treat Options Psychiatry. 2018;5(3):291-300.

62. Hempstead K, Phillips J. Divergence in recent trends in deaths from intentional and unintentional poisoning. Health Aff (Millwood). 2019;38(1):29-35.

63. Miller TR, Swedler DI, Lawrence BA, Ali B, Rockett IRH, Carlson NN, et al. Incidence and lethality of suicidal overdoses by drug class. JAMA Netw Open. 2020;3(3):e200607.

64. Ballester-Arnal R, Gil-Llario MD. The Virus that Changed Spain: Impact of COVID-19 on People with HIV. AIDS Behav. 2020;24:2253-2257

65. Shoptaw S, Goodman-Meza D, Landovitz RJ. Collective call to action for HIV/AIDS community-based collaborative science in the era of COVID-19. AIDS Behav 2020;24:2013-2016

Publisher's Note Springer Nature remains neutral with regard to jurisdictional claims in published maps and institutional affiliations. 